\title{
A River Cruise
}

\author{
Thomas M. Biggs
}

Published online: 14 March 2010

(C) Springer Science+Business Media, LLC and International Society of Aesthetic Plastic Surgery 2010

Despite my extremely fortunate life, I've never been on a river cruise. But I've been curious about such cruises, and I've fantasized one. The cruise I've fantasized has been different, however. It's been more like my life's journey. The cruise has moved constantly, enjoying a host of waters, some tranquil, some turbulent, but always ongoing. My travel companions have come and gone. Some have been with me from the beginning and still are onboard after many years, whereas others disembarked years ago. Some have come aboard along the way, staying a very short time or leaving, only to return later, and I've learned that we never know how long the passage will be.

As the cruise progressed, all of us onboard saw many interesting and changing things along the way. At times we stopped and went ashore to see and meet the inhabitants of different villages. In all the places our boat stopped, I met good people who gave me more than my share of attention and affection, and all had either a smaller or larger difference in their perspective on life and its consequences than I had.

Exposure to all these people has been invaluable in my assessment of the multifaceted nature of all things. Stopping and staying awhile in all these villages along the way made me realize that the goodness in people far outweighs the bad, and that even those who may seem unkind or dispirited have a heart beneath the facade of darkness they may have created around themselves. All of them-the quick and the dull, the educated and the intellectually isolated, the young and the old-have taught me and brought me joy.

T. M. Biggs $(\bowtie)$

1315 St. Joseph Parkway, Houston, TX 77002, USA

e-mail: tbiggsmd@aol.com
My cruise began in calm waters, with my parents as my only companions. As time went on and the river widened, I picked up school friends, teachers, and neighbors. During these times, my parents were so loving and approving that they actually did me a disservice, so that when I was 18 years old and went away from home to be thrown in with other boys from other places, I was forced into the realization that I wasn't the brightest kid in the world. As a matter of fact, I was just a tad above average. This was the first bit of rapids that shook my boat on the cruise.

People coming on and people getting off the boat, different sights along the shore every day, different villagesthe village of medical school, the village of residency, the village of the United States Air Force-all were great walks of experience with people who came and went, and I was the constant receiver of education. Lovely people came aboard. Some stayed for a long ride, and some are still aboard. My parents are gone, but my family has been with me throughout my cruise. When the waters became rough, it was the people onboard with me, my family and friends, who helped get us into calm waters again.

The village of my surgical experiences with more than 30,000 operations and my entry into ISAPS, where I learned that the bonds uniting us all are greater than the borders, boundaries, and languages that divide us, led me into the village of Aesthetic Plastic Surgery. As with all the villages I've encountered on my journey, this one has been educational. It's almost shocking to think that I considered myself so knowledgeable before I accepted the position of Editor-in-Chief because the amount I've learned in the past 7 years has been such an intense concentration of acquired knowledge that I have felt myself 18 again. This time, however, I had fooled myself, and I couldn't blame my parents. 
My knowledge gain has come from many sources. First, the writers of manuscripts have brought new information to my mind in ways I could never have found alone. There is a huge reservoir of untapped intellect "out there" just waiting to be exposed. Because our journal is written in English, much of this benefit hasn't been available to us, but those brave souls who've come forth in a language not primary with them have given me more than they know. They've also confirmed my suspicion that all the world's past and forward experiences were not and are not being written in English only.

Second, this small section of the ISAPS village has reviewers, those unheralded workers who are the foundation of a peer-reviewed journal. And all they get is a simple written thank you from Aesthetic Plastic Surgery once a year. The reviewers have written to me as a friend. They've all been cogent, and some of their reviews have risen to the quality of a textbook chapter. I cannot thank the reviewers enough for what they've done for Aesthetic Plastic Surgery and for how much they have taught me.

My companion through this village has been the Journal Operations Committee. The entire body has been reliable in their independent appraisals, prompt with their email communications, and always selfless in their dedication to the well-being not only of Aesthetic Plastic Surgery, but also of the entire plastic surgery family. Principal among these outstanding people has been Bryan Mendelson, a man of great honesty and dignity, and whose friendship I have come to treasure.

Of course, a publication must have a publisher, and I couldn't have wanted a more experienced and at the same time personable organization than Springer, with the inimitable Bill Curtis leading the team and Victoria Ferrara as his more-than-significant aide. Both have guided me with gentle and understanding persuasion.

I could not leave this section of the village without a fond goodbye to Suzann McClenahan, my umbilical connection to Aesthetic Plastic Surgery. We probably engaged in 20 or 30 emails a week and have become good friends, although we've never seen one another nor heard the other's voice.

The many joys and learning experiences I've acquired in the Aesthetic Plastic Surgery village would take up too many pages in an already restricted pages-per-issue arrangement, but I leave with great appreciation to all who've made my visit so enlightening and so joyful.

The sadness I feel as my river boat pulls away from the shore of the large ISAPS village, especially the beautiful neighborhood of Aesthetic Plastic Surgery, is softened somewhat by the realization that the trip is not over, that there are more sights along the way, and probably another village I can visit, with more people who have a different perspective on life. This is an exciting concept. My curiosity is alerted, and I know I'll soon begin fantasizing a new village with new people where I can continue to grow and feel and give the agape love that propels me in seeking the depth of man's ideals. Of course, when that fantasy begins to emerge from its amorphic state, I'll begin planning, fully expecting the execution of my plans, yet knowing all the while that at some point in time I'll leave that village with the joy of its memory. I can only hope that my next visit will bring me the excitement that the village of Aesthetic Plastic Surgery has brought me.

I've never been on a river cruise, but my life resembles one. What a fantastic cruise it has been so far and will continue to be. I live a fortunate life. 